\title{
Pain as the fifth vital sign: nurse's practices and challenges in a neonatal intensive unit care
}

\author{
A dor como quinto sinal vital: práticas e desafios do enfermeiro em uma unidade de terapia \\ intensiva neonatal
}

Marcela Milrea Araújo Barros ${ }^{1}$, Bruna Viana Scheffer Luiz¹, Claice Vieira Mathias ${ }^{1}$

DOI 10.5935/2595-0118.20190041

\section{ABSTRACT}

BACKGROUND AND OBJECTIVES: The importance of recognizing how the nurse acts in the identification, assessment, treatment, and relief of pain since the newborn is not able to express it orally. The objective of this study was to identify the practices and challenges of the nurse in the assessment and treatment of pain in newborns of a neonatal intensive care unit of a reference hospital in the western region of the Brazilian Amazon. METHODS: A descriptive, field-based, qualitative approach was chosen. Eleven nurses participated in the study, starting with an interview, following a semi-structured script. The content analysis method was used for data analysis.

RESULTS: The participants do not recognize the term "fifth vital sign" in the evaluation of pain, but they believe in the ability of the newborn to feel pain, identifying it mainly by the cry and facial expression. Among the procedures considered most painful are punctures and aspiration. Nurturing and non-nutritive sucking are among the actions most indicated to prevent and relieve pain.

CONCLUSION: We suggest the implementation of protocols, standards, and routines for the assessment and quantification of pain since when not assessed, it can prolong the hospitalization time. The perception of the nurse in the identification of pain signs in a systematized manner, promotes quality and humanized care, and reduces injuries.

Keywords: Newborn, Nurse, Pain.

\section{RESUMO}

JUSTIFICATIVA E OBJETIVOS: A importância de se reconhecer como o enfermeiro atua na identificaçáo, avaliação, tratamento e alívio da dor, uma vez que o recém-nascido não é capaz de expressá-la verbalizando. $\mathrm{O}$ objetivo deste estudo foi identificar as práticas e desafios do enfermeiro na avaliaçáo e tratamento da dor em recém-nascidos de uma unidade de terapia intensiva neonatal de um hospital de referência na região ocidental da Amazônia brasileira.

MÉTODOS: Optou-se por uma pesquisa descritiva, de campo, com abordagem qualitativa. Participaram do estudo 11 enfermeiros, a partir de entrevista, seguindo roteiro semiestruturado. Para análise de dados utilizou-se o método análise de conteúdo. RESULTADOS: Os participantes não reconhecem o termo "quinto sinal vital" na avaliação da dor, contudo acreditam na capacidade do recém-nascido sentir dor, identificando-a, principalmente pelo choro e expressão facial. Dentre os procedimentos considerados mais dolorosos destacam-se as punçóes e a aspiração. Dentre as açóes mais apontadas para prevenção e alívio da dor inclui-se o aninhamento e a sucção não nutritiva.

CONCLUSÁO: Sugere-se a implantação de protocolos, normas e rotinas para avaliação e quantificação da dor, visto que quando não avaliada, pode prolongar o tempo de internação. A percepção do enfermeiro na identificação dos sinais álgicos de maneira sistematizada, promove um atendimento de qualidade, humanizado e redução de lesóes.

Descritores: Dor, Enfermeiro, Recém-nascido.

\section{INTRODUCTION}

Pain is an uncomfortable sensation that can be defined as a sensorial, emotional, and subjective experience associated with actual or potential tissue damage ${ }^{1}$.

When pain is not treated, the newborn (NB) may suffer detrimental effects due to persistent catabolism, activation of the sympathetic system, alteration in the cardiovascular system, and may trigger intense anxiety and delirium ${ }^{2}$. NB pain has been object of study for the last four decades, thus proving that as of the $16^{\text {th }}$ week there is the capacity to transmit pain impulses through the cerebral cortex, and after the $26^{\text {th }}$ week its mechanism of transmission is completed, being able to respond to nociceptive stimuli through organic, behavioral and physiological changes ${ }^{3}$.

In Neonatal Intensive Care Units (NICU), the NB are exposed to several painful procedures, including loud noises, ex- 
cessive light, frequent manipulation, and repeated necessary procedures, resulting in physiological disorganization where the energy reserves that would be directed to growth are used to stabilize the $\mathrm{NB}^{4}$.

Pain is understood as a complex and individual experience, manifested by physiological and body signs ${ }^{2}$. It is considered the fifth vital sign by the American Agency for Research and Quality in Public Health and the American Pain Society, that recommends that it must be recorded like the other vital signs ${ }^{5}$.

The interest in the study is the result of the need to address pain in the NB considering its particularity, the repercussions that can be generated in the short and long term, and the importance of recognizing how the nurse acts in the identification, assessment, treatment and relief of pain since the NB cannot express it orally.

Identifying and assessing pain is both an obstacle and a challenge for nurses. Professionals sensitivity to NB pre-verbal language is essential so that they can provide appropriate and humanized treatment to meet their needs ${ }^{6}$.

Added to the discussions and reflections originated, comes the question that guides this research: does the nurse recognize pain as the fifth vital sign?

The objective of this study was to identify the practices and challenges of nurses to assess and treat pain in NB of a NICU of a reference hospital in the western region of the Brazilian Amazon.

\section{METHODS}

We opted for a descriptive, field research, with a qualitative approach, using interviews with a semi-structured script, recorded and fully transcribed. The Hospital de Base Dr. Ary Pinheiro is a public hospital, a reference care center in the Northern region, located in the city of Porto Velho - Rondônia, with 26 NICU beds. Data collection was from March to April 2017.

NICU nurses who voluntarily agreed to participate in the study were included. Those who were absent during the data collection period due to vacation or leave of absence were excluded. The final sample consisted of 11 nurses. For the analysis of the results, the content proposed by Minayo ${ }^{7}$ was used. The study followed the parameters of Resolution no. 466 of December 12, 2012, of the National Health Council/Department of Health that rules research with humans. The participants received the Free and Informed Consent Term (FICT) when the research objectives were clarified. The board of directors authorized the interviews, and the Human Research Ethics Committee of the Faculdades Integradas Aparício Carvalho (FIMCA) approved, under opinion number 1,782,126, on October 19, 2016.

\section{RESULTS}

The research sample consisted of 11 professional nurses working in the hospital's NICU. Using the assumptions of con- tent analysis, it was possible to understand and describe the perception of the nurses regarding the importance to assess, prevent, and relieve the pain of the NB in a NICU. After reading the full transcribed reports, it was noticed that each professional assesses pain in a unique way, without using the protocols or the scales recommended by the Department of Health. From the analysis of the statements, based on similar and convergent reports, four thematic groups were listed: the nurse's perception of pain as the $5^{\text {th }}$ vital sign in the NICU, the process of pain identification and assessment, the procedures considered most painful, and the care provided by nurses for pain prevention and relief.

\section{DISCUSSION}

The various painful stimuli in the neonatal period cause changes in several organs and systems, resulting in increased neonatal morbidity and mortality ${ }^{8}$. NB admitted to the NICU receive, on average, 53 painful stimuli, and an average of $65 \%$ of the procedures do not have adequate analgesia ${ }^{3}$. Nurses working in the unit surveyed believe that in the NICU, pain is present in almost all manipulations and procedures. All nurses interviewed recognized that the NB can feel pain:

[...] it is present in everything we do, in the manipulation of these little babies and in most procedures [...] they feel pain (Jade).

Pain is present in $99.9 \%$ of the newborns [...] (Crystal).

Pain will always be present in the care of NB, and they can perceive it more intensely than older children and/or adults due to the immaturity of the inhibitory control, reducing the ability to modulate painful experiences. So, it is up to the nurse to evaluate and define the most appropriate treatment method, thereby promoting the well-being of the NB'

Care of NB should include principles to minimize painful interventions, including strategies such as routine pain assessment, reduction of bedside procedures, use of scientifically proven measures to prevent and relieve pain as non-pharmacological and pharmacological measures ${ }^{4}$.

The American Agency for Public Health Research and Quality and the American Pain Society describe it as the fifth vital sign, and it should be assessed and recorded along with the other vital signs: temperature, pulse, respiration, and blood pressure?.

In the same vein, the Joint Commission on Accreditation of Healthcare Organizations, a North American entity of hospital evaluation, published in 2000 a standard that includes pain as the fifth vital sign. The standard determines that pain should be measured, as well as the other vital signs, being standardized in all health institutions. Pain measurement must be standardized, and its recording should become a routine to doctors and nurses providing care ${ }^{10,11}$.

Regarding the nurses' perception related to the theme, it was noticed that they do not recognize pain as the fifth vital sign, and therefore, they do not evaluate it systematically. 
I haven't heard about this nomenclature [...] this is the first time I hear it. I don't know if it's new or if I don't know [...] (Pérola). I know nothing about the fifth vital sign in our unit [...] look, to tell the truth, I do not remember [...] (Esmeralda).

This result contradicts the findings in a study conducted at a university hospital in Paraná regarding pain verification, pointing out that $79.3 \%$ of the professionals evaluated it with the other vital signs ${ }^{11}$.

The study shows the fragility and inconsistency of knowledge regarding this subject, and the statements show that participants do not use the nomenclature "pain as the fifth vital sign".

In a study conducted in the Northwest region of Rio Grande do Sul, the participants, even though they did not perform the appropriate measurement, were aware of the nomenclature and also stated that the fifth vital sign should be evaluated, treated and recorded like the other physiological parameters ${ }^{12}$.

The assessment of pain in NB is a challenge for health professionals because it is a subjective phenomenon, in addition to the inability of NB to report it verbally. Due to this lack of oral communication from patients, it is essential that nurses working in neonatal units be aware of this very different language, expressed through actions, to provide full and safe care to the $\mathrm{NB}^{13}$.

When asked about pain identification and assessment, nurses reported difficulties related to their inability to verbalize according to the following statements:

\section{[...] it is complicated to explain because it is a patient who does not speak [...] (Rubi). \\ [...] it is not very easy, but we try to identify [...] (Safira).}

The non-verbalization of the pain they experience is still considered a hurdle by the nursing staff. The NB express their pain by their behavior, and the team should be prepared to recognize and interpret the signs after painful and stressful stimuli ${ }^{14}$.

When asked about the use of scales, frequency, and assessment protocols, it was found that there are no protocols and routines for pain management and no methods for pain measurement. Professionals acknowledge being knowledgeable about the scales, but admit the lack of daily practice:

$[\ldots]$ there is no scale, we know it exists, but no scale is used here in the sector [...] (Jade).

[...] there are no protocols here [...] (Diamante).

[...] actually, there is a pain scale, but it is not applied. (Ágata).

Nurses analyze pain in NB in different ways, based on their values and prior and individual knowledge, which may have repercussions on the patient's clinical status, allowing the occurrence of iatrogenesis in care, thus violating the principles of patient safety ${ }^{1}$.

Pain assessment in NB has been performed incipiently, by individual analyzes of each professional, adopting particular criteria and without standardization, hindering a proper treatment ${ }^{15}$.
Regarding the identification and signs that lead them to perceive pain, it was observed that crying and facial expressions are the most used behavioral manifestations for their perception:

[...] more stable baby, it's crying [...] we know by the face, right? some wrinkle the forehead, makes that face of pain, of suffering (Safira).

Through inborn reflexes such as crying or facial expression (Onix). [...] crying is one of the manifestations of pain, sometimes the baby is sedated or is little reactive, we notice some frowning [...] (Diamante).

With similar results, a NICU survey in four public hospitals in Fortaleza, in the state of Ceará, showed that most nurses assess pain by observing changes in the baby's behavior such as crying and changes on the face ${ }^{15}$. The use of behavioral signs is considered the primary method to assess pain by the nursing staff ${ }^{13,16}$.

Crying is considered the NB primary communication method since it mobilizes the adult, the mother or the health professional, and it can limit the professional when diagnosing pain since many babies do not cry during painful procedures. When assessing pain, one should consider that other factors can make the NB cry, such as hunger and discomfort ${ }^{17}$.

Considering that painful stimuli cause behavioral changes that may or may not be associated with other signs, the professional should be vigilant to these signs. It was noticed in the studied NICU, that the professionals are aware and do pay attention to physiological alterations, as reported:

(...) becomes tachycardic, saturation drops (...) (Jade).

(...) tachycardia, is what we notice most in the baby by the monitoring we have, right? (Diamante).

(...) saturation decrease (...) increased respiratory rate (...) increased heart rate (Turquesa).

In a study with 13 health professionals of a NICU in Mossoró, state of Rio Grande do Norte, the respondents used as parameters to identify pain, the crying, the face, behavioral changes, and changes in vital signs ${ }^{18}$. Physiological manifestations are important to assess pain in the clinical practice, but they should not be used isolated to determine if the NB has pain but added to the behavioral parameters ${ }^{19}$.

Among the invasive procedures performed during hospitalization in neonatal units, which is often an arduous, iatrogenic and stressful process for both the NB and the assisting staff, the puncture with a short peripheral vascular catheter stands out, mainly due to the vesicant characteristics of most life support components used ${ }^{1}$.

When asked about the most painful procedures, the nurses cited punctures in general as the most painful stimuli, as follows:

$[\ldots]$ heel-stick when it is for glycemia [...] or the Guthrie test and venipuncture, but I think it hurts more on the foot because the pain 
continues after the puncture, unlike the venipuncture that only hurts at the moment (Safira).

[...] venipuncture that happens almost routinely [...] (Esmeralda). Everything related to puncture, sticking, sample collection, blood gas, access puncture are the most painful (Cristal).

In a study conducted with nursing assistants in Ceará about the procedures performed in the NICU, several are considered painful, including venipuncture, 25 (100\%), capillary, 10 (40\%), arterial $8(32 \%)$, and lumbar puncture, $8(32 \%)^{20}$.

Heel-stick is recommended for tests that require a small amount of blood, for example, the foot test, hematocrit, total bilirubin, venous blood gas analysis, and glucose. Blood collected in the heel stick can be used for many other therapeutic purposes, thus preventing more painful stimuli to infants. Making better use of this process benefits both the practitioner who can perform other tasks rather than spending time on unnecessary interventions and the patient who will not undergo so many painful stimuli ${ }^{21}$.

The peripherally inserted central catheter (PICC) is a central venous catheter that is implanted in a peripheral vein for safe drug administration, total parenteral nutrition, and long-term hypertonic solutions in central veins. The introduction of PICC is a painful procedure, and the pain repeated several times may delay the recovery of the $\mathrm{NB}^{22}$.

During the interview, the nurses mentioned the importance of using PICC because it provides a longer period of use and, even with the discomfort to the NB at the time of insertion, it prevents the frequent manipulation in search of peripheral venous access. In the following statements, it can be observed that such a procedure was cited as one of the most painful processes:

[...] venipuncture, whether peripheral or central PICC [...] (Ágata). Some invasive procedures [...] peripheral puncture [...] here, 90\% of newborns have a PICC [...], so we end up causing this pain to the baby [...] (Rubi).

Most NB in NICU are premature. As a result, there is inadequate development of the lungs and other injuries. During the field research, it was observed that many NB were on artificial airways. From this perspective, the nurses interviewed cited secretion aspiration as a painful procedure, according to the following reports:

Tube suction (Safira).

Tracheal suction [...] (Pérola).

In practice, I would say that the most painful is tracheal suction in the intubated [...] (Turmalina).

In order to investigate the behavioral manifestations of preterm infants hospitalized in high-risk units, it was observed that at the moment of the tracheal suction, crying and twisting movements were the predominant manifestations of the NB. Tracheal suction is of paramount importance for the pulmonary mechanical ventilation therapy since most of them are dependent and, although it seems simple, it requires rigorous care to avoid unde- sirable effects, especially due to the organic immaturity of these patients ${ }^{23}$.

Analgesia should be individualized for all NB with potentially painful diseases or those undergoing invasive surgical procedures or not. Although the world current consensus on the importance of pain control, health professionals are often unable to identify and treat $\mathrm{it}^{24}$.

There are now several alternatives to avoid unnecessary pain and suffering in hospitalized NB because, in addition to pharmacological therapy, the nursing staff can use alternative measures and effective relief and discomfort during hospitalization ${ }^{25}$.

Non-pharmacological methods are noninvasive techniques to minimize pain and comprise of a set of emotional, physical, educational, and behavioral measures, most of them with minimal risk of complication, low cost, and easy application. In Brazil, the most commonly used methods involve facilitated tuck in, swaddling, music therapy, environment, the kangaroo method and breastfeeding, non-nutritive sucking, positioning, and the use of glucose $\mathrm{e}^{19}$.

The theoretical and practical knowledge of nurses related to pain is fundamental because only then the NB can receive the proper prevention and necessary care, bringing comfort and safety to the $\mathrm{NB}$ as shown in the following statements:

\section{[...] We nestle the baby [...] (Cristal).}

[...] We promote comfort nestling the baby [...] we wrap it in its own sheet [...] (Rubi).

[...] We do it before to prevent the pain, we wrap it like a cigar [...] (Safira).

Nestling is a non-pharmacological method for pain relief and comfort, scientifically effective because it simulates the intrauterine position, creating a sense of safety, comfort, and self-organization while minimizing the loss of body heat to the environment. This care consists of bending the upper and lower limbs, reducing the psychological and behavioral response of stress and pain in $\mathrm{NB}^{26}$.

Swaddling helps the self-regulation of the NB during stressful and painful procedures, with the principle of maintaining the midline. Care that includes changing the baby's position, swaddling, nestling, maintaining a bent position, and providing hand-held postural support help the organization and self-regulation of $\mathrm{NB}^{27}$.

Since pain is harmful, the diagnosis is as important as the treatment. To prevent and relieve pain, nurses use non-nutritive suction.

[...] we give a non-nutritive suction and a little glove [...] (Safira). [...] we improvise a pacifier with a glove and gauze [...] (Esmeralda).

Non-nutritive sucking is generally used to maintain the well-being of the NB when painful and invasive procedures are required, and it can be used as a therapeutic measure, enabling the psychosomatic and somatic self-regulation of the NB. It is recommended to reduce pain scores in mild to moderately painful procedures and should be routinely used ${ }^{27}$. 


\section{CONCLUSION}

With the nurses' reports, it was possible to understand the relevance of proper pain management since when it is not assessed, it can prolong the hospitalization time. The nurse's perception in identifying pain signs provides humanized care, minimizing injuries.

\section{REFERENCES}

1. Santos LM, Pereira MP, dos Santos LF, de Santana RC. [Pain assessment in the premature newborn in Intensive Care Unit]. Rev Bras Enferm. 2012;65(1):27-33. Portuguese.

2. Falcấo AC, Sousa AL, Stival MM, Lima LR. Abordagem terapêutica da dor em neonatos sob cuidados intensivos: uma breve revisăo. $\mathrm{R}$ Enferm Cent $\mathrm{O}$ Min. 2012;2(1):108-23.

3. Alves CO, Duarte ED, Azevedo VM, Nascimento GR, Tavares TS. Emprego de soluçôes adocicadas no alívio da dor neonatal em recém-nascido prematuro: uma revisão integrativa. Rev Gaúcha Enferm. 2011;32(4):788-96.

4. Aquino FM, Christoffel MM. Dor neonatal: medidas nâo-farmacológicas utilizadas pela equipe de enfermagem. Rev Rene. 2010;11(n. esp):169-77.

5. Lemos NR, Caetano EA, Marques SM, Moreira DS. Manejo de dor no recém-nascido: revisẫo de literatura. Rev Enferm UFPE. 2010;4(n. esp):972-9.

6. Bottega FH, Benetti ER, Benetti PE, Gomes JS, Stumm EM. Evaluation of pain in neonates and children in intensive care. J Res Fundam Care. 2014;6(3):909-17.

7. Minayo MCS. O desafio do conhecimento: pesquisa qualitativa em saúde. $14^{\mathrm{a}}$ ed. Sấo Paulo: Editora Hucitec; 2015.

8. Ministério da Saúde (Brasil). Ministério da Saúde. Secretaria de Atençăo à Saúde. Departamento de Açóes Programáticas Estratégicas. Atenção à saúde do recém-nascido: guia para os profissionais de saúde / Ministério da Saúde. Vol 2 - 2a ed. atual - Brasília: Ministério da Saúde, 2014.

9. Nascimento LA, Kreling MC. Avaliaçấo da dor como quinto sinal vital: opiniāo de profissionais de enfermagem. Acta Paul Enferm. 2011;24(1):50-4.

10. Ribeiro NC, Barreto SC, Hora EC, de Sousa RM. [The nurse providing care to trauma victims in pain: the fifth vital sign]. Rev Esc Enferm USP. 201145(1):146-52. Portuguese.

11. Queiróz DT, Carvalho MA, Carvalho GD, Santos SR, Moreira AS, Silveira MF. Dor $5^{\circ}$ sinal vital: conhecimento de enfermeiros. Rev Enferm UFPE. 2015; 9(4):7186-92.
12. Bottega FH, Fontana RT. A dor como quinto sinal vital: utilização da escala de avaliação por enfermeiros de um hospital geral. Texto Contexto Enferm. 2010;19(2):283-90.

13. Silva PC, Marinho EF, Santos LO. A percepçáo dos profissionais de saúde sobre a dor em prematuros. Rev Diálogos \& Ciência. 2016;16(36):39-51.

14. Rodrigues JB, Barbosa DS, Werneck AL. Identificação e avaliaçấo da percepção dos profissionais de enfermagem em relação a dor/desconforto do recém-nascido. Arq Ciênc Saúde. 2016;23(1):27-31.

15. Oliveira RM, Siebra e Silva AV, Chaves EM, Sales NC. Avaliação comportamental e fisiológica da dor em recém-nascidos pelos profissionais de enfermagem. REME - Rev Min Enferm. 2010;14(1):19-24.

16. Martins SW, Dias FS, Enumo SR, Paula KM. Avaliação e controle da dor por enfermeiras de uma unidade de terapia intensiva neonatal. Rev Dor. 2013;14(1):21-6.

17. Costa R, Cordeiro R. Desconforto e dor em recém-nascido: reflexôes da enfermagem neonatal. Rev Enferm UERJ. 2016;24(1):e11298.

18. Duarte SR, Nunes AP, Carvalho CS, Paiva WW, Barbosa FW, Monteiro AI. Assistência de enfermagem ao recém-nascido com dor em uma unidade de terapia intensiva neonatal. J Nurs UFPE. 2014;9(7):2382-9.

19. Presbytero R, Costa ML, Santos RC. Os enfermeiros da unidade neonatal frente ao recém-nascido com dor. Rev Rene. 2010;11(1):125-32.

20. Mendes LC, Fontenele FC, Dodt RC, Almeida LS, Cardoso MV, Silva CB. A dor no recém-nascido na unidade de terapia intensiva neonatal. Rev Enferm UFPE. 2013;7(11):6446-54

21. Gaíva MA, Silva FB, Azevedo FM, Rubira EA. Procedimentos dolorosos em recém-nascidos prematuros em unidade terapia intensiva neonatal. Arq Ciênc Saúde. 2014;21(1):48-54

22. Kegler JJ, Paula CC, Neves ET, Jantsch LB. Manejo da dor na utilizaçáo do cateter central de inserçáo periférica em neonatos. Esc Anna Nery. 2016;20(4):e20160099.

23. Balbino AC, Cardoso MV, Silva RC, Moraes KM. Recém-nascido pré-termo: respostas comportamentais ao manuseio da equipe de enfermagem. Rev Enferm UERJ. 2012;20(5):615-20.

24. Silva YP, Gomez RS, Máximo TA, Silva AC. Avaliação da dor em neonatologia. Rev Bras Anestesiol. 2007;57(5):565-74

25. Veronez M, Corrêa DA. A dor e o recém-nascido de risco: percepçáo dos profissionais de enfermagem. Cogitare Enferm. 2010;15(2):263-70.

26. Oliveira CW, Silva JV, Rodrigues AP, Xavier Júnior FS, Tenório GM. Intervençôes nāo farmacológicas no alívio da dor em unidade de terapia intensiva neonatal. Ciências Biológicas e da Saúde. 2016;3(2):123-34.

27. Christoffel MM, Castral TC, Daré MF, Montanholi LL, Gomes AL, Scochi CG. Atitudes dos profissionais de saúde na avaliação e tratamento da dor neonatal. Esc Anna Nery. 2017;21(1):e20170018. 